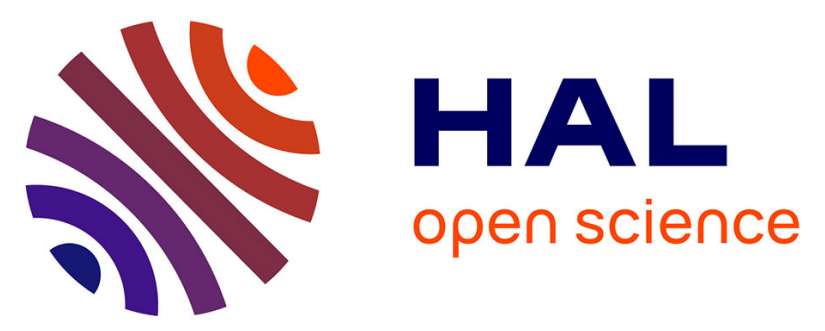

\title{
Oil spill effects on macrofaunal communities and bioturbation of pristine marine sediments (Caleta Valdés, Patagonia, Argentina): experimental evidence of low resistance capacities of benthic systems without history of pollution
}

\author{
Agustina Ferrando, Emilia Gonzalez, Marcos Franco, Marta Commendatore, \\ Marina Nievas, Cécile Militon, Georges Stora, Franck Gilbert, José Luis \\ Esteves, Philippe Cuny
}

\section{To cite this version:}

Agustina Ferrando, Emilia Gonzalez, Marcos Franco, Marta Commendatore, Marina Nievas, et al.. Oil spill effects on macrofaunal communities and bioturbation of pristine marine sediments (Caleta Valdés, Patagonia, Argentina): experimental evidence of low resistance capacities of benthic systems without history of pollution. Environmental Science and Pollution Research, 2015, vol. $22\left(\mathrm{n}^{\circ} 20\right)$, pp. 15294-15306. 10.1007/s11356-015-4167-6 . hal-01223400

\author{
HAL Id: hal-01223400 \\ https://hal.science/hal-01223400
}

Submitted on 2 Nov 2015

HAL is a multi-disciplinary open access archive for the deposit and dissemination of scientific research documents, whether they are published or not. The documents may come from teaching and research institutions in France or abroad, or from public or private research centers.
L'archive ouverte pluridisciplinaire HAL, est destinée au dépôt et à la diffusion de documents scientifiques de niveau recherche, publiés ou non, émanant des établissements d'enseignement et de recherche français ou étrangers, des laboratoires publics ou privés. 


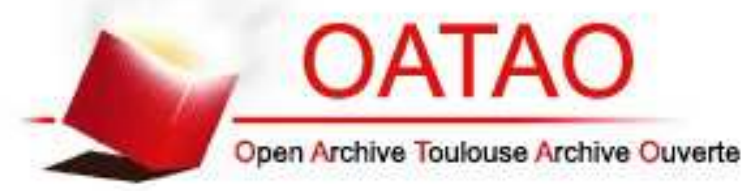

\section{Open Archive TOULOUSE Archive Ouverte (OATAO)}

OATAO is an open access repository that collects the work of Toulouse researchers and makes it freely available over the web where possible.

This is an author-deposited version published in : http://oatao.univ-toulouse.fr/ Eprints ID : 14432

To link to this article : doi: $10.1007 / \mathrm{s} 11356-015-4167-6$

URL : http://dx.doi.org/10.1007/s11356-015-4167-6

To cite this version : Ferrando, Agustina and Gonzalez, Emilia and Franco, Marcos and Commendatore, Marta and Nievas, Marina and Militon, Cécile and Stora, Georges and Gilbert, Franck and Esteves, José Luis and Cuny, Philippe Oil spill effects on macrofaunal communities and bioturbation of pristine marine sediments (Caleta Valdés, Patagonia, Argentina): experimental evidence of low resistance capacities of benthic systems without history of pollution. (2015) Environmental Science and Pollution Research, vol. 22 ( $\left.{ }^{\circ} 20\right)$. pp. 15294-15306. ISSN 0944-1344

Any correspondance concerning this service should be sent to the repository administrator: staff-oatao@ listes-diff.inp-toulouse.fr 


\title{
Oil spill effects on macrofaunal communities and bioturbation of pristine marine sediments (Caleta Valdés, Patagonia, Argentina): experimental evidence of low resistance capacities of benthic systems without history of pollution
}

\author{
Agustina Ferrando • Emilia Gonzalez • Marcos Franco • \\ Marta Commendatore - Marina Nievas • Cécile Militon • \\ Georges Stora • Franck Gilbert • José Luis Esteves • \\ Philippe Cuny
}

\begin{abstract}
The Patagonian coast is characterized by the existence of pristine ecosystems which may be particularly sensitive to oil contamination. In this study, a simulated oil spill at acute and chronic input levels was carried out to assess the effects of contamination on the macrobenthic community structure and the bioturbation activity of sediments sampled
\end{abstract}

Responsible editor: Philippe Garrigues

Electronic supplementary material The online version of this article (doi:10.1007/s11356-015-4167-6) contains supplementary material, which is available to authorized users.

A. Ferrando $(\bowtie) \cdot$ M. Franco $\cdot$ M. Commendatore $\cdot$ M. Nievas $\cdot$ J. L. Esteves

Centro Nacional Patagónico (CENPAT - CONICET), Bvd. Brown 2915, Puerto Madryn 9120, Argentina

e-mail: ferrando@cenpat-conicet.gob.ar

\section{E. Gonzalez}

Universidad Nacional de la Patagonia San Juan Bosco (UNPSJB), Bvd. Brown 3000, Puerto Madryn 9120, Argentina

\section{Franco $\cdot$ M. Nievas}

Universidad Tecnológica Nacional, Facultad Regional Chubut, Av. del Trabajo 1536, Puerto Madryn 9120, Argentina

C. Militon · G. Stora • P. Cuny

Aix Marseille Université, CNRS, Université de Toulon, IRD, MIO

UM 110, Marseille 13288, France

F. Gilbert

Université de Toulouse, INP, UPS, EcoLab (Laboratoire Ecologie

Fonctionnelle et Environnement), 118 Route de Narbonne,

31062 Toulouse, France

F. Gilbert

CNRS; EcoLab, Toulouse 31062, France in Caleta Valdés creek. Superficial sediments were either noncontaminated or contaminated by Escalante crude oil and incubated in the laboratory for 30 days. Oil contamination induced adverse effects on macrobenthic community at both concentrations with, for the highest concentration, a marked decrease of approximately 40 and $55 \%$ of density and specific richness, respectively. Besides the disappearance of sensitive species, some other species like Oligochaeta sp. 1, Paranebalia sp., and Ostracoda sp. 2 species have a higher resistance to oil contamination. Sediment reworking activity was also affected by oil addition. At the highest level of contamination, nearly no activity was observed due to the high mortality of macroorganisms. The results strongly suggest that an oil spill in this protected marine area with no previous history of contamination would have a deep impact on the non-adapted macrobenthic community.

Keywords Macrobenthic communities · Oil pollution · Bioturbation · Resistance capacities · Pristine marine sediments $\cdot$ Patagonia

\section{Introduction}

In quantitative terms, crude oil is the most important organic contaminant in the marine environment (Spormann and Widdel 2000; Head et al. 2006). Despite the implementation of active and preventative policies, inputs are still increasing due to the rise of the world consumption and transportation, mainly via maritime routes, of petroleum products (Dargay and Gately 2010). Oil hydrocarbons are either chronically or 
accidentally introduced in many marine areas around the world. They can affect coastal and marine ecosystems in several ways. For instance, toxic effects of some hydrocarbons, particularly polycyclic aromatic hydrocarbons, on feeding, growth, development, and reproduction cascade across trophic levels affecting plankton, fish, marine birds and mammals, as well as benthic organisms (Fleeger et al. 2003; NRC 2003; Wiese and Ryan 2003; Alonso-Alvarez et al. 2007; González et al. 2009; Engraff et al. 2011; Almeda et al. 2013; Bellas et al. 2013; Lee and Lin 2013). The deposition of hydrocarbons or oil/weathered oil at the sediment-water interface can considerably alter the biogeochemistry of benthic systems and impact inhabiting organisms that maintain a close relationship with these substrates (Rivero et al. 2005; Massara Paletto et al. 2008). In particular, reduced diversity, retrogression to opportunistic species, and reduced size of individuals have been reported for macrobenthic organisms in contaminated sediments (Lee and Page 1997; Peso-Aguiar et al. 2000; Blanchard et al. 2002; Belan 2003; Je et al. 2003; Lu 2005; Gomez Gesteira and Dauvin 2005; Lu and Wu 2006; Di Leonardo et al. 2007; Venturini et al. 2008; Gonzalez Egres et al. 2012; Yu et al. 2013; Seo et al. 2014; Zabbey and Uyi 2014). Yet, soft-bottom macrobenthic organisms play a key role in processes such as organic matter degradation and nutrient cycling, dissolved oxygen diffusion, dispersion and burial of sediment particles, and secondary production (Michaud et al. 2006; Gilbert et al. 2003). This is mainly due to excavation or ingestion of mud and particulate organic matter (Rhoads et al. 1978; Aller 1982; Kristensen et al. 2012). Bioturbation was recently redefined by Kristensen et al. (2012) as the displacement of particles (sediment reworking) and solutes (ventilation) due to the infauna activity. These bioturbating organisms, through the construction of tunnels and canals, particularly alter the flow of dissolved oxygen within marine sediments (Pischedda et al. 2008; Pischedda et al. 2012) and thereby positively influence microbial activities (Arndt et al. 2013). This subsequently affects significantly early diagenesis and, more particularly, biodegradation rates and pathways of organic pollutants (Gilbert et al. 1996; Christensen et al. 2002; Banta and Andersen 2003; Granberg et al. 2005; Mermillod-Blondin and Rosenberg 2006; Cuny et al. 2007; Miralles et al. 2007; Cuny et al. 2011; Stauffert et al. 2013). Conversely, bioturbation may be responsible for a large release of contaminant from the sediment into the water column (Thibodeaux and Bierman 2003; Cuny et al. 2011).

In case of contamination, the effects of oil on macrobenthic communities may thus in turn strongly affect the natural attenuation and, overall, the resistance and resilience capacities of the benthic system. Sediments chronically contaminated generally exhibit tolerant or opportunistic species populations, usually polychaetes worms, which can resist to relatively elevated concentrations of hydrocarbons (Gilbert et al. 1996; Peso-
Aguiar et al. 2000; Grossi et al. 2002; Dauvin and Ruellet 2007; Miralles et al. 2007; Seo et al. 2014; Gilbert et al. 2015). In contrast, pristine benthic communities without historical exposure to hydrocarbons seem to be particularly sensitive to contamination (Carman et al. 2000). To date, the literature related to oil effects on pristine areas is still scarce, probably because more and more areas around the world are exposed to chronic or massive hydrocarbon spillages. Yet, in this kind of oil-sensitive marine area, a single large spill of crude oil or petroleum products may produce environmental damages that can amount to billions of dollars (Dalton and Jin 2010).

Human activities in coastal areas involve port and industrial activities and maritime transport. Patagonian coast extends over more than $3000 \mathrm{~km}$ between $40^{\circ}$ and $55^{\circ} \mathrm{S}$ and oil production is one of the most important economic activities in the region. There are two important oil basins named San Jorge and Austral basins, which produce petroleum in the order of 17.8 million $\mathrm{m}^{3}$ per year, constituting nearly $50 \%$ of the Argentina total annual production (Nievas and Esteves 2007). The main risk of Patagonian marine ecosystems contamination comes from crude oil loading in buoys and ports and maritime transport from exploitation sites in the south to the refineries in the north of the Country. Although hydrocarbon pollution was found in some punctual zones of the Patagonian coastal sediments (Comendatore et al. 2000; Esteves et al. 2006; Commendatore and Esteves 2007; Commendatore et al. 2012), certain areas such as Caleta Valdés (CV; east of Península Valdés; Chubut province) have been never affected by massive or chronic pollution and remain pristine (unpublished data, Commendatore and Esteves). This ecosystem, established as Humanity Mundial Patrimony (UNESCO 1999) because it is a sensitive zone that constitutes a valuable environment for the reproduction and feeding of birds and marine mammalians, offers a relatively unique opportunity of assessing the response of the macrobenthic communities in case of petroleum contamination.

The objective of this work was to experimentally ex situ study the effects of a simulated oil spill at acute and chronic concentration levels on the macrobenthic community structure and the bioturbation activity of sediments sampled in a pristine site located in Caleta Valdés. Pollution-induced changes in macrobenthic community with a special interest for the determination of indicator species, as well as changes of the reworking activity, were assessed after 30 days of incubation.

\section{Materials and methods}

\section{Study area}

Caleta Valdés (CV) is a north-south oriented creek located at the eastern side of the Peninsula Valdés and connected 
to the Atlantic Ocean by a southern mouth. The sampling site for the experimentation was chosen in the muddy north continental zone of CV $\left(42^{\circ} 15^{\prime} 53^{\prime \prime} \mathrm{S}, 63^{\circ} 40^{\prime} 50^{\prime \prime}\right.$ $\mathrm{W})$ because of the absence of anthropogenic hydrocarbon pollution and it macrofauna richness (Fig. 1).

Bioturbation experimental assay conditions

\section{Sampling}

Sediment samples were collected by hand in April 2012 using $10 \mathrm{~cm}$ diameter and $25 \mathrm{~cm}$ length tubes, in agreement with previous works on bioturbation and reworking studies (Timmermann et al. 2002; Quintana et al. 2007; Hedman et al. 2011). Twelve PVC corers were vertically introduced down to $20 \mathrm{~cm}$ sediment depth approximately. Then, they were carefully withdrawn and carried immediately to the laboratory avoiding disturbing the vertical structure of the sediments. Surficial sediment (first centimeter; $4 \mathrm{~kg}$ ) was also collected for the laboratory experimentation. In addition, $20 \mathrm{~L}$ of seawater were also collected in plastic containers.

\section{Laboratory experimental design and incubation conditions}

With the aim to assess the oil impact on macrobenthic community structure and activity, three experimental conditions were set up: a control condition without oil addition (E0; 4 sediment cores), a low hydrocarbon concentration condition (E1; 4 sediment cores), and a high hydrocarbon concentration condition (E2; 4 sediment cores). These conditions were carried out by depositing at the surface of the respective cores, a layer of surficial CV sediments (height: $1 \mathrm{~cm}$ ) either noncontaminated (E0), or contaminated by Escalante crude oil (Chubut) at final concentrations of $1000 \mathrm{ppm}(1 \mathrm{~g} / \mathrm{kg}$; E1) and $20000 \mathrm{ppm}(20 \mathrm{~g} / \mathrm{kg}$; E2). The different amounts of added oil were defined to simulate chronic and acute polluted sites, respectively (UNEP/IOC 1992). Then, the three groups of four cores were respectively distributed in three individual 56.1 L tanks. Tanks were filled with seawater, previously collected in $\mathrm{CV}$, until cores were covered. They were then kept aerated (air bubbling) and monitored periodically during experimentation. In order to assess biological reworking activity, in each sediment core, $2 \mathrm{~g}$ of luminophores (63-355 $\mu \mathrm{m}$ particulate inert tracers, Duport et al. 2007) were homogeneously spread at the sediment surface at two different experimental times: green particles at initial time ( $t=0$ days $)$ and pink particles 15 days after the start of the experiment ( $t=15$ days). Luminophores size was selected according to the sediment granulometry. Cores were incubated statically for 30 days at ambient temperature, after which they were manually collected and sliced in order to provide $0.5 \mathrm{~cm}$ thick sediment layers from the surface to $2 \mathrm{~cm}$ depth and $1 \mathrm{~cm}$ thick layers from 2 to $18 \mathrm{~cm}$. Each sediment slice was then separated in four equal parts that were randomly distributed to perform the different further analysis.

Fig. 1 Sampling site in Caleta Valdés (CV; Península de Valdés, Patagonia Argentina)

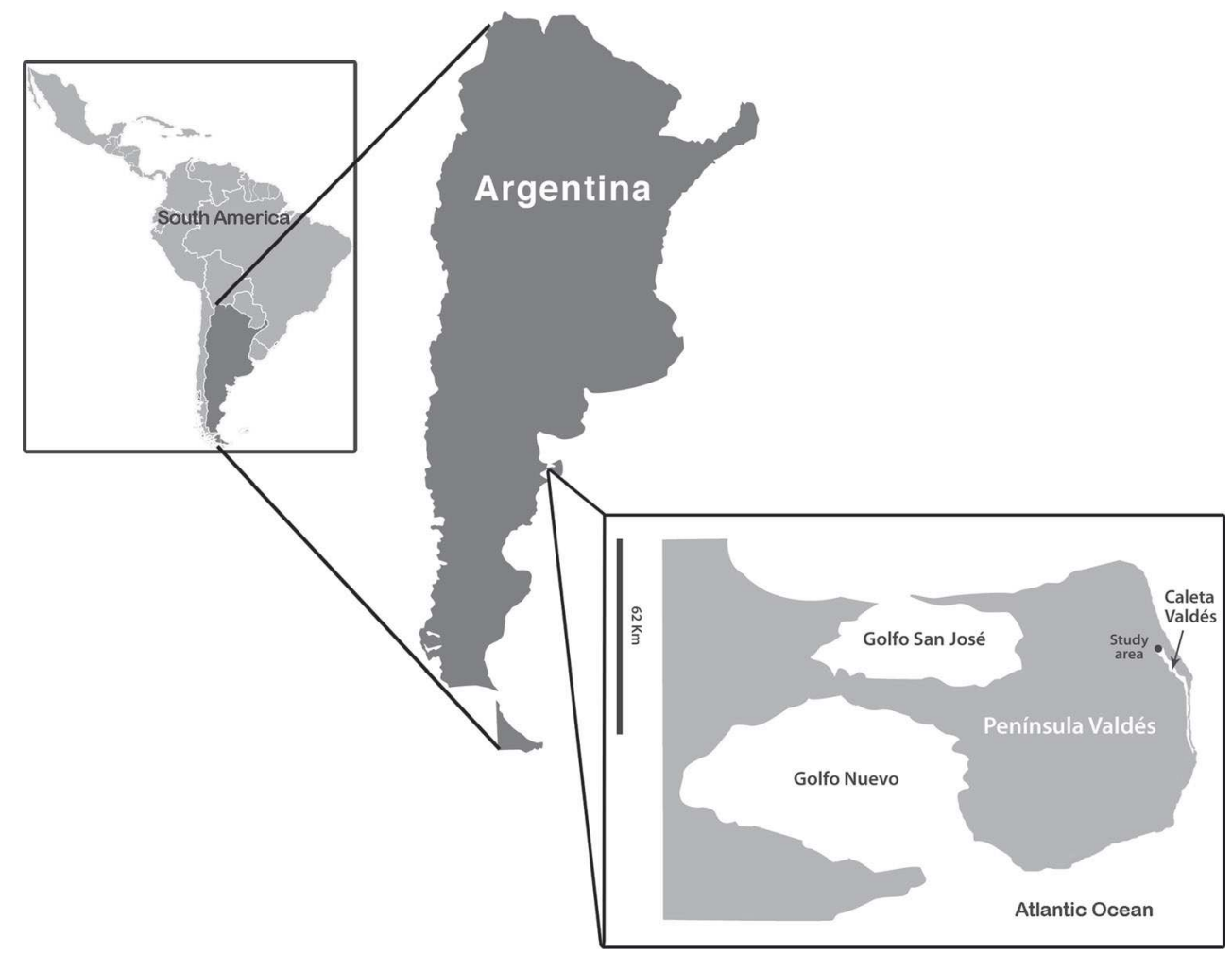




\section{Variable assessment}

Temperature, dissolved oxygen, and $\mathrm{pH}$ were assesses periodically in the microcosm sea water during the experiments using a multiparameter probe YSI-556.

\section{Analytical procedures}

\section{Macrobenthic communities}

The $75 \%$ of each layer (i.e., three parts) obtained from of each corer was fixed with $4 \%$ formaldehyde to perform macrobenthic community analysis, storing the one resting parts at $-20^{\circ} \mathrm{C}$ for chemical analysis. The fixed samples were first sieved with a $500 \mu \mathrm{m}$ mesh to retain macroorganisms and then with a $44 \mu \mathrm{m}$ mesh to collect the sediment fraction containing the luminophores particles. The sediment retained on the $500 \mu \mathrm{m}$ mesh was preserved in alcohol $70 \%$ for the counting and sorting of the organisms. The macrofauna was identified to the major taxonomic level possible with stereoscopic and optic microscopes using reference keys (Hartman 1968; 1969; Banse and Hobson 1974; Blake and Ruff 2007; Orensanz et al. inedited, among others). Whole organisms and anterior fragments of each taxon were only registered. In order to provide more information that could support further studies, some classification parameters usually used in taxonomic identification and photographs of the three major undetermined species or group of species are presented in the Online Resource 1.

\section{Bioturbation}

The vertical luminophores profile of each sediment column at final time of experimentation (30 days) was obtained from the percentages of the luminophores found in each layer with respect to the total amount in the core. The sediment retained on the $44 \mu \mathrm{m}$ mesh was homogenized and subsampled to quantify luminophores using a microplate reader (Biotek Synergy Mx) at $\lambda$ ex/ $\lambda$ em: $565 / 602$ and $460 / 500 \mathrm{~nm}$ for the green and pink luminophores, respectively. According to the respective time of deposition of the tracers at the surface of the cores, data from green particles reflected the reworking activity from the whole experimentation period (30 days), while pink particles indicate activity during the last 15 days.

The quantification of sediment reworking was evaluated from the distributions of luminophores by the gallerydiffusor model (François et al. 2002). This model allows to describe both the biodiffusion-like transport ( $D_{b}$ coefficient) due to the continuous displacement of the tracers and the nonlocal advective displacement of the tracers ( $r$ coefficient). The best fit between observed and modeled tracer distribution with depth (i.e., producing the best $D b$ and $r$ coefficients couple) was estimated by the least squares method (Gilbert et al. 2007).

Statistical data analysis

Data analyses were performed by corer using the software package PRIMER 5.0 (Plymouth Marine Laboratory, UK). Specific richness $(S)$, total abundance (expressed as density $=$ number of individuals $/ \mathrm{m}^{2}$ ), the Shannon diversity index $\left(H^{\prime}\right)$, and Pielou's evenness index $\left(J^{\prime}\right)$ were calculated for each treatment. Differences in each biological variable were evaluated through one-way ANOVA considering conditions as fixed factors $(n=12)$ (Statistica, version 7$)$. The Tukey test for multiple mean comparisons was used to determine statistically significant differences between conditions.

The ordination and sorting using the total abundance data was carried out with a non-metric multidimensional scaling (nMDS) and CLUSTER analysis (Bray-Curtis index; group average link; square root), respectively. The differences between the macrobenthic communities composition were tested by ANOSIM (Similitude analysis) while SIMPER (Similitude Percentage) was applied to determine the species that most contributed to the observed differences (PRIMER 5.0 program).

Finally, the dominant and subdominant species per treatment were calculated according to Picard (1965). The species were considered dominant or subdominant when the mean dominance index was maximum or $\geq 5 \%$, respectively.

A comparison of the biodiffusion $\left(D_{b}\right)$ and bioadvection ( $r$ ) coefficients was performed to assess differences in the sediment transport along the sediment column between the experimental conditions by means of the non parametric Kruskal-Wallis one-way analysis of variance by ranks (Kruskal and Wallis 1952). When significant, it was followed by a Mann-Whitney pairwise comparison test to evaluate the significance of the differences between conditions after a Bonferroni adjustment for multiple comparisons (Siegel and Castellan 1988).

\section{Results}

Physico-chemical parameters

The seawater temperature, dissolved oxygen, and $\mathrm{pH}$ showed little changes throughout the incubation with mean values of $17.7 \pm 0.6^{\circ} \mathrm{C}, 7.9 \pm 0.4 \mathrm{mg} / \mathrm{L}$, and $7.8 \pm 0.3$, respectively $(n=7)$ for all the experimental conditions. There were no statistically significant differences of means found between conditions (E0, E1, E2) for these three variables. 


\section{Macrobenthic communities}

Experiments with two levels of oil addition affected macrobenthic community structure in comparison with the control experiment, being these changes mainly evidenced in density and specific richness (Fig. 2a, b, Online Resource 2). The contamination caused a progressive reduction in both parameters with the added oil amount showing a negative tendency. Particularly, the addition of $20 \mathrm{~g} / \mathrm{kg}$ of oil (E2) resulted in a decrease of approximately 40 and $55 \%$ of density and specific richness, respectively. On the other hand, diversity and evenness showed little changes being diversity only significantly lower for E2 condition in comparison with E1 treatment. The low level contamination condition (E1) did not differ from control for these two parameters (Fig. 2c, d, Online Resource 2).

The density, specific richness, diversity, and evenness profiles of organisms vs. depth layers are shown in Fig. 3. In a general way, the maximum values of these parameters were found in the first $2 \mathrm{~cm}$, and then they gradually decreased with depth. Density was mainly affected by oil addition in the superficial layer of the sediments $(0-0.5 \mathrm{~cm})$ where a decrease of approximately 54 and $78 \%$ was observed for the lowly (E1) and highly (E2) contaminated cores, respectively. Specific richness, diversity, and evenness markedly decreased with depth for the highly contaminated cores compared to controls and lowly contaminated cores.

The nMDS and CLUSTER analysis showed that the E1 samples were close to the E0 samples with a $72 \%$ of similarity while the E2 samples, which were located on the opposite side of the diagram, presented a $58 \%$ of similarity with E0 and E1 (Fig. 4, Online Resource 3). The nMDS representation was satisfactory as attested by the low stress value $(0.11)$.
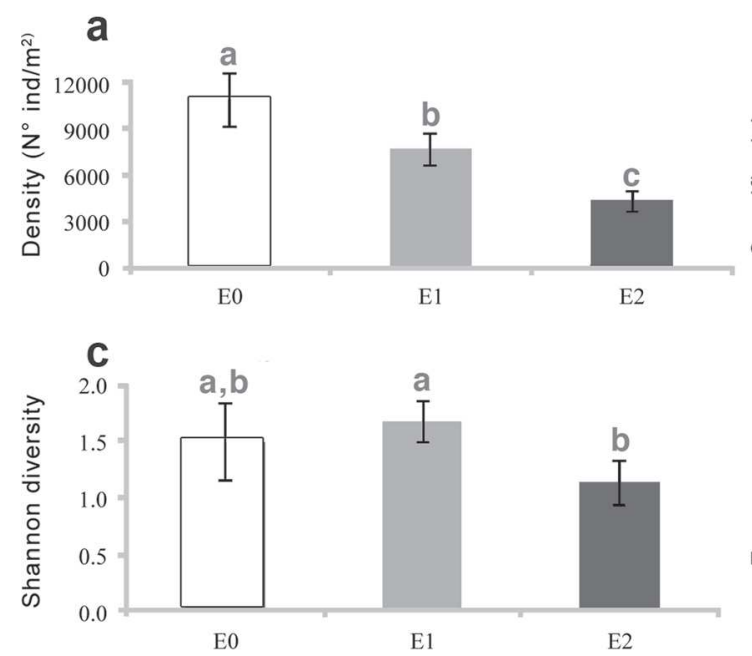

Fig. 2 Global community parameters measured for each experimental condition (mean values for the entire cores \pm standard deviation; $n=4)$. E0 control (no contamination); E1 low oil contamination (1 g/kg); E2 high
The ANOSIM showed highly significant differences among conditions with a global $\mathrm{R}$ of $0.775(p<0.02)$. The SIMPER results showed which species contributed in greater extent to the differences observed. Higher proportions of Ostracoda sp. 1, Oligochaeta sp. 1, Pseudocumatidae sp. 1, Leuroleberis poulseni and Cirolanidae sp. 1 were observed in noncontaminated sediments. Low and high contaminated sediments were characterized by the presence of Ostracoda sp. 2, Phoxocephalopsis sp., Ceratocephale sp., Anacalliax argentinensis and Gammaridae sp. 2, and Paranebalia sp., respectively (Table 1).

Lastly, a list of the dominant and subdominant species found in the oil pollution simulation experiments is given in Table 2. Ostracoda sp. 1 was the dominant species in the E0 (uncontaminated) and E2 (highly contaminated) conditions. This species was the most subdominant species in the E1 experience where Ostracoda sp. 2 predominated over there. Finally, Oligochaeta sp. 1 was the most subdominant species in the E2 experience.

\section{Sediment reworking: luminophores vertical distribution}

The vertical distribution of the luminophores showed an exponential decrease of the tracers with depth for the three experimental conditions (Fig. 5). Maximal penetration depth for the luminophores was of $14 \mathrm{~cm}$ for all conditions (data not shown) with more than $96 \%$ of tracers located in the first $5 \mathrm{~cm}$ (Fig. 5). After 30 days of incubation, nearly all the green luminophores remained at surface $(98 \%)$ for the highly contaminated cores (E2) while for low contaminated (E1) and uncontaminated (E0) only 54 and $43 \%$ of the initially deposited luminophores were detected in the deposit zone, respectively (Fig. 5a). The effects of oil addition were even more marked during the last 15 days
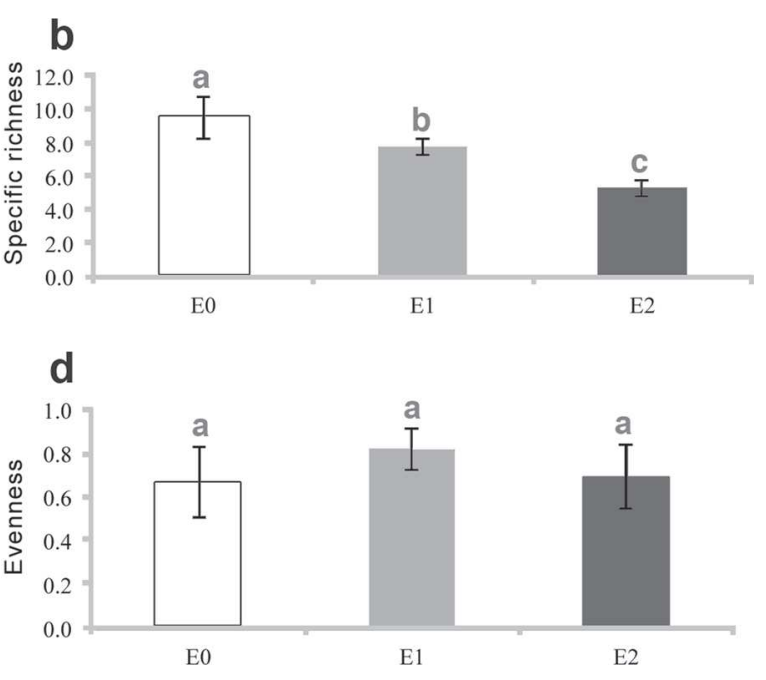

oil contamination $(20 \mathrm{~g} / \mathrm{kg})$. Lowercase letters indicate significant differences between experimental conditions 
Fig. 3 Community parameters measured at each depth layer for each condition (mean values; $n=$ 4). EO control (no contamination); E1 low oil contamination $(1 \mathrm{~g} / \mathrm{kg}) ; E 2$ high oil contamination $(20 \mathrm{~g} / \mathrm{kg})$

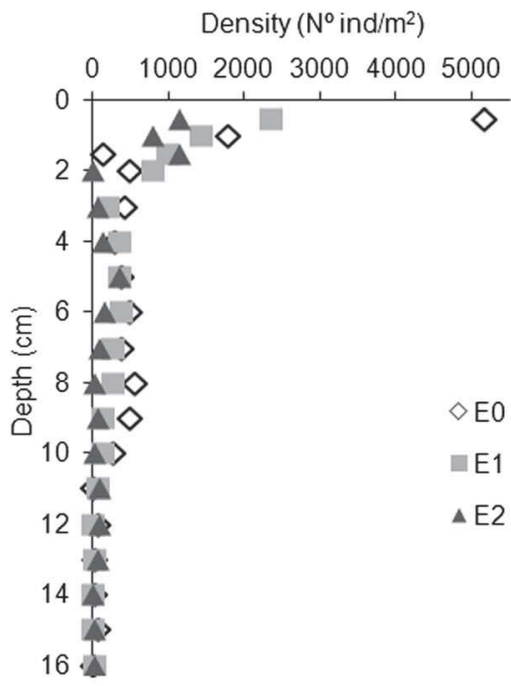

Shannon diversity

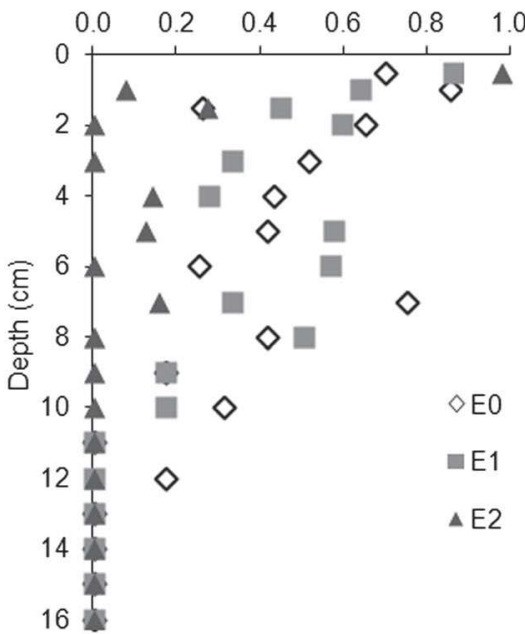

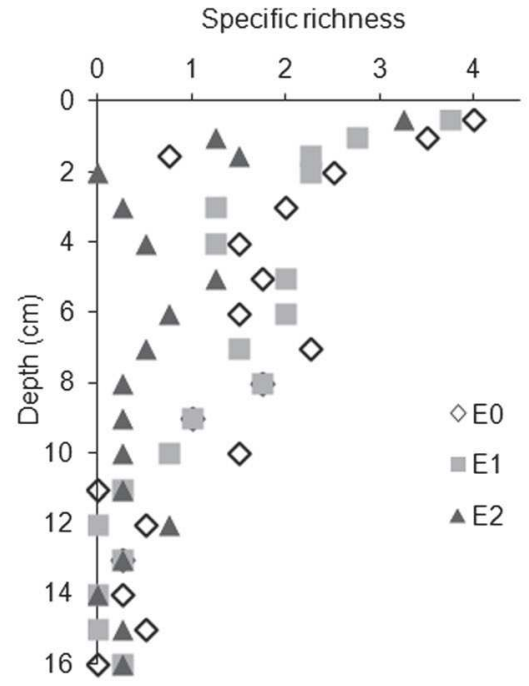

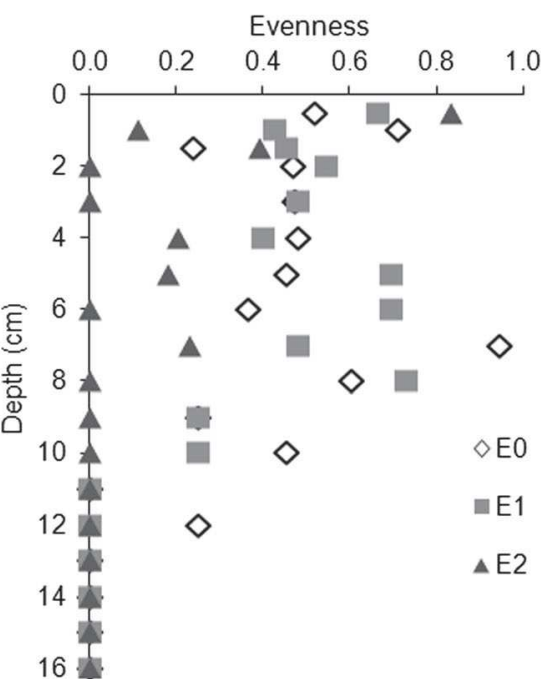

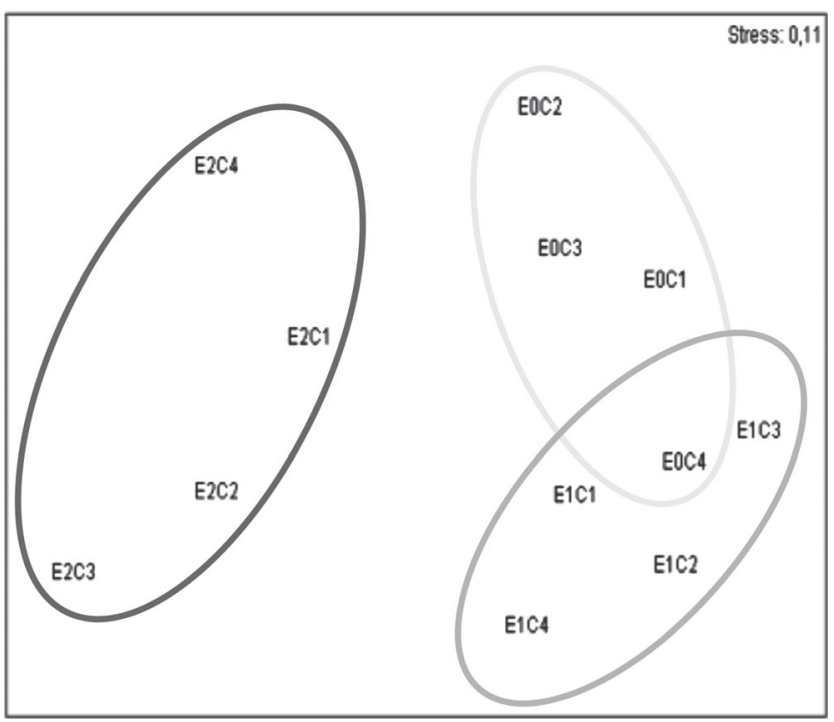

Fig. 4 Non-metric multidimensional scaling diagram (nMDS) for each condition (transformation: square root). E0 control (no contamination); E1 low oil contamination $(1 \mathrm{~g} / \mathrm{kg})$; E2 high oil contamination $(20 \mathrm{~g} / \mathrm{kg})$
Table 1 Similarity percentage analysis (SIMPER) for oil pollution simulation experiments

\begin{tabular}{llll}
\hline \multirow{2}{*}{ Species } & \multicolumn{3}{l}{ Mean abundance } \\
\cline { 2 - 4 } & E0 & E1 & E2 \\
\hline Ostracoda sp. 1 & 44.50 & 16.75 & 15.25 \\
Oligochaeta sp. 1 & 14.25 & 5.50 & 12.00 \\
Axiothella sp. & 10.25 & 10.25 & 0.75 \\
Ostracoda sp. 2 & 5.25 & 18.75 & 3.50 \\
Phoxocephalopsis sp. & 4.00 & 4.25 & 0.00 \\
Pseudocumatidae sp. & 3.50 & 0.75 & 0.75 \\
Paranebalia sp. & 1.00 & 0.25 & 1.25 \\
Leuroleberis poulseni & 1.00 & 0.50 & 0.00 \\
Cirolanidae sp. 1 & 0.75 & 0.25 & 0.00 \\
Ceratocephale sp. & 0.50 & 0.75 & 0.25 \\
Anacalliax argentinensis & 0.25 & 1.25 & 0.00 \\
Gammaridae sp. 2 & 0.25 & 1.50 & 0.00
\end{tabular}

EO control (no contamination), E1 low oil contamination $(1 \mathrm{~g} / \mathrm{kg}), E 2$ high oil contamination $(20 \mathrm{~g} / \mathrm{kg})$ 
Table 2 Dominant and subdominant species in oil pollution simulation experiments

\begin{tabular}{|c|c|c|c|c|c|c|c|c|}
\hline \multicolumn{3}{|l|}{ E0 } & \multicolumn{3}{|l|}{ E1 } & \multicolumn{3}{|l|}{ E2 } \\
\hline Species & $P$ & $D$ & Species & $P$ & $D$ & Species & $P$ & $D$ \\
\hline Ostracoda sp. 1 & 1112.50 & 51.74 & Ostracoda sp. 2 & 468.75 & 30.86 & Ostracoda sp. 1 & 381.25 & 44.85 \\
\hline Oligochaeta sp. 1 & 356.25 & 16.57 & Ostracoda sp. 1 & 418.75 & 27.57 & Oligochaeta sp. 1 & 300.00 & 35.29 \\
\hline Axiothella sp. & 256.25 & 11.92 & Axiothella sp. & 256.25 & 16.87 & Ostracoda sp. 2 & 87.50 & 10.29 \\
\hline \multirow[t]{2}{*}{ Ostracoda sp. 2} & 131.25 & 6.10 & Oligochaeta sp. 1 & 137.50 & 9.05 & & & \\
\hline & & & Phoxocephalopsis sp. & 106.25 & 7.00 & & & \\
\hline
\end{tabular}

E0 control (no contamination), E1 low oil contamination ( $1 \mathrm{~g} / \mathrm{kg}), E 2$ high oil contamination $(20 \mathrm{~g} / \mathrm{kg})$. $P$ mean density, $D$ mean dominance index

of the experiments (Fig. 5b). Indeed, the percentages of buried pink luminophores were only 26 and $1 \%$ for E1 and E2, respectively, while $47 \%$ were moved down from the surface deposition layer for the controls.

Quantification of sediment reworking showed significant differences in the biodiffusion coefficient $\left(D_{b}\right)$ between the control and the highly contaminated condition $(p<0.05)$ for both the full experience time (30 days) and the last 15 days in comparison with controls (Fig. 6a, b, Online Resource 2). The same pattern was found with the bioadvection coefficient $(r$ ) (Fig. 6c, $\mathrm{d}$, Online Resource 2). Both coefficients indicated a decrease of sediment reworking intensity with oil concentration increase with almost null values for the highly contaminated sediments. Indeed, in the presence of the high contamination (E2), the 0.1 values given by the model for both $D b$ and $r$ are the lowest limit values of the model (i.e., they vary from 0 to 0.1 ).

\section{Discussion}

Caleta Valdés is a pristine zone in the Patagonian coast having no oil contamination history. Simulated ex situ oil spills were conducted to study the impact of oil on the structure and activity of the macrobenthic community at two levels of contamination, low and high, simulating a chronic pollution and an acute oil spill situation, respectively. Throughout the whole experimentation, water temperature, dissolved oxygen, and $\mathrm{pH}$ within experimental tanks were stable for all the incubation conditions, suggesting that these were not discriminating parameters.

Resistance of macrobenthic community to oil contamination

The results clearly demonstrate the low resistance capacities to oil contamination of the macrobenthic communities of Caleta Valdés sediments. Castège et al. (in press) studied benthic community from Guéthary (Bay of Biscay, France), affected by the Prestige oil spill in 2002 . These authors concluded that 5 years after the spill, the macrobenthic community still showed perturbation signs, such as proliferation of grazers, highlighting the complexity and slowness of the recovery process. The severity of oil impacts on the benthic macrofauna depends on many factors, most notably (1) oil amount; (2) chemical composition; (3) form (weathered or not, emulsified
Fig. 5 Vertical profiles of luminophores distribution after 30 days of experimentation and for the last 15 days. $E 0$ control (no contamination); $E 1$ low oil contamination $(1 \mathrm{~g} / \mathrm{kg})$; E2 high oil contamination $(20 \mathrm{~g} / \mathrm{kg})$
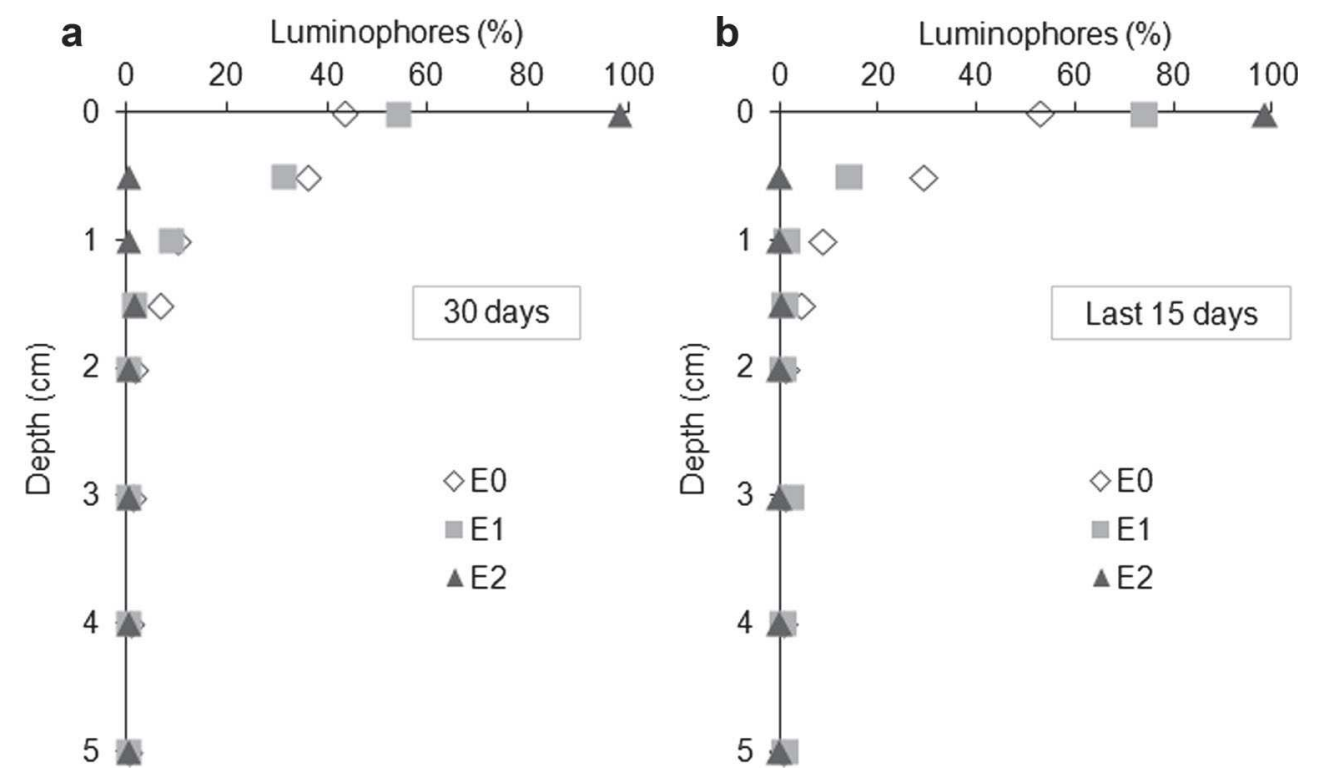
Fig. 6 Sediment reworking biodiffusion $\left(D_{b}\right)$ and bioadvection $(r)$ coefficients after 30 days of incubation and for the last 15 days. $E 0$ control (no contamination); $E 1$ low oil contamination $(1 \mathrm{~g} / \mathrm{kg})$; E2 high oil contamination $(20 \mathrm{~g} / \mathrm{kg})$. Note that, in presence of the high contamination (E2), the 0.1 values given by the model for both $D b$ and $r$ are the lowest limit values of the model (i.e., they vary from 0 to 0.1 ). Lowercase letters indicate significant differences between experimental conditions a

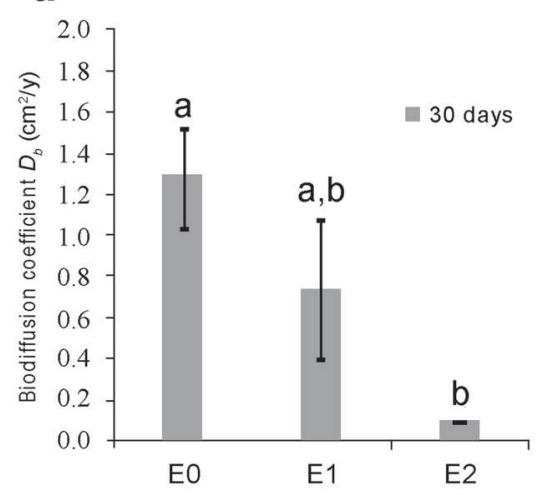

C

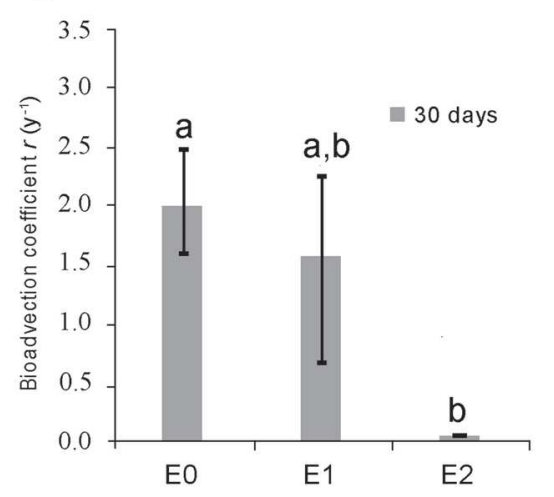

b

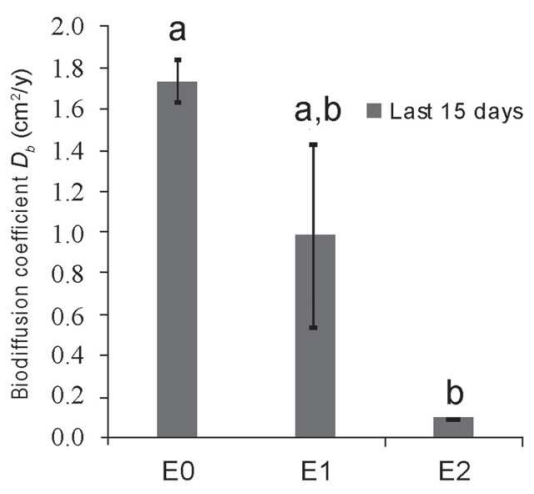

d

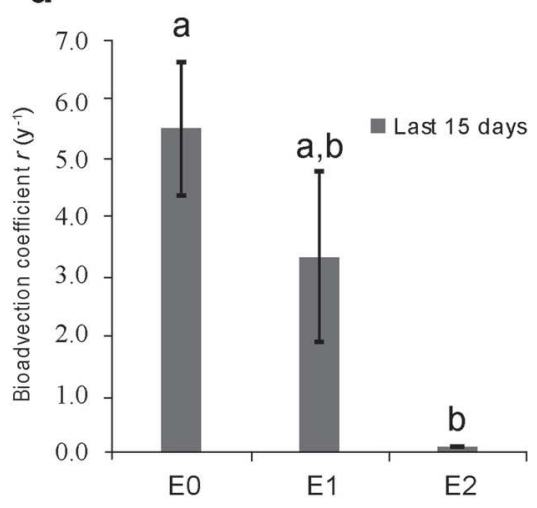

or not, type of emulsion); (4) occurrence (i.e. solubilized, in suspension, dispersed, or adsorbed on suspended particulate matter); (5) exposure time; (6) life stage (juvenile or adult forms); (7) season; (8) natural environmental stress associated with fluctuations in temperature, salinity, and other variables; and (9) type of affected environment (Kennish 1997). According to Puente et al. (2009), fine-grained substrates characterized by low permeability and water-saturated sediments, such as the one used in this study, substantially prevents depth penetration of oil. Indeed, the high surface/ volume ratio of the sedimentary matrix grains facilitates oil absorption and retention in the superficial layers preventing oil penetration to deep layers. This phenomenon was probably reinforced by our experimental setup, i.e., no simulation of sediment re-suspension due to tidal currents. Such conditions may explain why the density of macrobenthic organisms was mainly affected in the most superficial layer of contaminated sediment (i.e., where the oil was applied). At the same time, no deeper burial of the organisms in order to avoid contamination was detected (Bolam 2011), suggesting a direct toxic impact of the oil compounds on the organisms. According to Baker (1970), low molecular weight compounds present in oil can dissolve the membranes and alter the biota respiration mechanisms. Particularly, the oil water-accommodated fraction (WAF) containing the most polar and low molecular weight compounds from oil, mainly aromatic hydrocarbons (PAHs), have been extensively described to be toxic. For example, $\mathrm{LC}_{50}$ on benthic organisms of oil WAF were found to be as low as $1.2-3 \mathrm{ppm}$ of total aromatic hydrocarbon for some amphipods, shrimps, crabs, and snails (Holdway 2002), while Echols et al. (2015) reported $>20 \%$ mysid mortality for Gulf of Mexico crude oil WAF in a concentration range of $0.015-$ $0.89 \mathrm{ppm}$ of total PAHs. Escalante crude oil used in our experiments is classified as medium petroleum having low molecular weight compounds aromatic hydrocarbons. A concentration of $1.38 \mathrm{ppm}$ of total BTEXs and $0.23 \mathrm{ppm}$ of total PAHs from naphthalene up to traces of four aromatic ring compounds like pyrene were measured in the Escalante oil WAF in a 90:1 (seawater:oil) ratio volume mixture (Marino et al. 2012). Thus, a top-down gradient of these compounds in the water phase of the oiled experimental cores may be expected due to diffusion processes. This fact may also explain the mortality found in the top layer, in addition to the direct contact of organisms with the organic oil phase.

Regarding oil effect on the structure of macrobenthic community, both the density and specific richness of organisms decreased with regard to the uncontaminated controls with a progressive impact with the increasing oil contamination. Harmful effects of crude oil on different macrobenthic communities have been previously reported. For instance, Hartwick et al. (1982) carried out field and laboratory studies about the effect of Alberta crude oil on behavior and survival of 
natural littleneck clam (Protothaca staminea) populations from uncontaminated sites during 231 and 10 days, respectively. In both studies, superficial sediments were contaminated with different oil concentrations and no mortality was found through the experimental period when the clams were treated with crude oil at $1000 \mathrm{ppm}$, the same concentration used in our study for the low concentration experiment (E1). Nevertheless, siphon activities were impaired at this contamination level; this functional inhibitory effect would probably render the animals more vulnerable to natural mortality factors (e.g., predation) in their habitat. In another study, carried out in Singapore coasts chronically contaminated by discharges from industry, sewage, and shipping, a significantly negative correlation between the specific richness, abundance, and diversity of macrobenthic organisms and total petroleum hydrocarbons was found (for oil added at concentration $>800 \mathrm{ppm})(\mathrm{Lu} 2005)$.

Response of the different macrobenthic species to oil contamination

Benthic organisms with little or no mobility have been widely used in marine environmental impact assessment and monitoring. As a matter of fact, they are sensitive sensors of physical and chemical changes undergone by benthic systems (e. g., Dauer 1993; Poulton et al. 1998; Muniz et al. 2005; Gomez Gesteira and Dauvin 2005; Borja and Dauer 2008; Ocon et al. 2008; Dauvin et al. 2010). Because they are closely associated with the seafloor they can hardly avoid deteriorated conditions of water and/or sediment quality. Furthermore, they have relatively long life cycles and exhibit different stress tolerance (Bilyard 1987; Dauer 1993). According to their response to stress, species can be divided into "sensitive species" (i.e., able to only survive within a narrow range of environment conditions and disappear from polluted areas); "tolerant species" (i.e., being not sensitive to a particular stress and/or pollution); "opportunistic species" (i.e., able to quickly exploit new recourses or ecological niches as they become available, characterized by early reproduction, high reproduction rates, rapid development, small body size, and an uncertain adult survival rate), and "indifferent species" (without real affinity for any particular community and showing no response to pollution) (Dauvin et al. 2010). In Caleta Valdés sediments and with regard to our experimental oil contamination, the three first types of organisms were found. Opportunistic species could be represented by Oligochaeta sp. 1 that reached high densities under the highly contaminated conditions (E2). Different opportunistic species of oligochaetes have been shown to be favored by the organic enrichment of sediments due to discharge of sewage outfall (Gamito 2008), untreated abattoir wastes (Arimoro et al. 2007) and livestock effluents (Solimi et al. 2000). These substrates are mostly covered by bacteria and sewage fungi, which are the main food source for the most part of oligochaetes (Rueda et al. 2003). Species such as Limnodrilus hoffmeisteri and Tubifex tubifex have been used as indicators of this kind of environment (Brinkhurst and Jamieson 1971; Aston 1973; Miserendino and Pizzolon 2000). Particularly, Gonzalez Egress et al. (2012) found a marked decrease in the density of oligochaetes shortly after the in situ diesel oil spill impact but a recovery trend with a gradual increase from day 2 , behaving as tolerant or resilient species to the oil impact (Gomez Gesteira and Dauvin 2000; Ocon et al. 2008). Also, Paranebalia sp. (Crustacea: Phyllocarida: Leptostraca) was dominant in the most contaminated sediments 30 days after the oil addition and seems to be a tolerant species. Even if it was known as a primarily tropical-subtropical genus, it was recorded for the first time in the northern Patagonia during the years 2003 to 2007 on sediments and among holdfast of Macrocystis pyrifera and Undaria pinnatifida (Roccatagliata et al. 2010). Leptostracans are known to occur in a variety of habitats, from hydrothermal vents and marine caves to the intertidal zone showing a wide resistance to adverse environmental conditions (Haney and Martin 2004). Under mild contaminated conditions (E1) Ostracoda sp. 2 was the dominant species at the end of the incubation. Yet, previous field and laboratory studies demonstrated that ostracods seem particularly sensitive to oil (Carman et al. 2000; Ruiz et al. 2005). Nevertheless, after a high mortality event due to the introduction of oil, it has also been observed a high recovery capacity of ostracods communities characterized by the development of high densities, 2 days after the contamination (Gonzalez Egress et al. 2012), or by changes in the trophic structure of the community (Carman et al. 2000). Clearly, the response of the different species of ostracods may vary. Indeed, in the present study, Ostracoda sp. 1 predominated both under uncontaminated and highly contaminated conditions but its abundance decreased with the oil addition. On the other side, some taxa known for their sensibility to contamination such as Phoxocephalopsis sp. (Gomez Gesteira and Dauvin 2000) also disappeared when superficial sediments were highly contaminated (E2). The present study constitutes the first characterization of the macrobenthic communities of Caleta Valdés sediments both subject or not to oil contamination. This perturbation led to the selection or disappearance of particular organisms which may serve as indicator species for this kind of environment in case of oil pollution. However, although our results do provide a first indication about potential oil pollution indicators, further studies are needed in order to identify the macrobenthic organisms to species level (e.g., ostracods) but also characterize their functional traits. This information is so far clearly missing for the Patagonian coastal zone where exploitation and sea transportation of oil are rapidly expanding. 
Role of the benthic organisms in the polluted sediments natural attenuation

Benthic biota has a marked role in microbial aerobic biodegradation of hydrocarbons in marine sediments (Cuny et al. 2011). Indeed, bioturbation processes such as burrow construction and ventilation carried out mainly by macrofauna are key process to stimulate the availability of oxygen in superficial sediments (Timmermann et al. 2008). In addition, some macrobenthic organisms can affect positively the biodegradation of hydrocarbons through the production of digestive compounds acting like surfactants that modify their dispersion state and improve their bioavailability (Penry and Weston 1998; Weston and Mayer 1998; Gilbert et al. 2001) for hydrocarbon-degrading bacteria (Bertrand et al. 1993; Bonin and Bertrand 1999; Cuny et al. 2007; Cuny et al. 2011). Therefore, in sediments strongly affected by oil spills without active macrobenthic fauna, the microbial bioremediation of hydrocarbons would be markedly reduced (Timmermann et al. 2011).

In the frame of this study, oil affected the structure but also the activity of the Caleta Valdés macrobenthic community. Indeed, the quantification of the sediment reworking clearly showed a negative impact of oil contamination on the transport and mixing of particles by organisms. This impact was highlighted in highly contaminated conditions by the almost null values of the biodiffusion $\left(D_{b}\right)$ and bioadvection $(r)$ coefficients calculated for the full experience and for the last 15 days of incubation. These facts evidenced a general reduction of sediment reworking for both mixing modes with oil addition. This suggests that the activity of the community was inhibited throughout the sedimentary column, even in deeper sediments where community parameters were not strongly affected by oil. Similar observations have been reported for laboratory experiments where Nereis diversicolor reworking was found to be reduced in the presence of Arabian Light crude oil (Gilbert et al. 1994). But this is not always the rule, as other authors have found that Hediste diversicolor reworking activity may be enhanced in case of oil contamination (Stauffert et al. 2013). These discrepancies underline the complexity of the response of the benthic system to oil contamination, which is controlled by several factors as mentioned above. Overall, the different responses to oil pollution will be given by the resistance capacity of the species according to their biological traits, physiological status, and stage of development.

Finally, the resistance capacity seems to be strongly determined by the different events of contamination that may have led to the selection of an adapted community. As highlighted by the weak resistance capacity to oil of the macrobenthic communities of Caleta Valdés, pristine environments without previous history of contamination would be probably strongly impacted in case of an oil spill (Carman et al. 2000).
In conclusion, this study allowed for the first time to experimentally evaluate the effects of oil exploited in Patagonia on the structure and activity of the benthic macrofauna from a pristine site located in Caleta Valdés. Macrobenthic community structure, and above all, sediment reworking activity were impacted even at the lowest contamination level tested (level corresponding to chronically contaminated sites). On the other hand, in a high level of contamination, similar to those recorded in intertidal areas after an oil spill, results demonstrated an almost complete inhibition of macroorganisms reworking activity. It further causes severe structural changes in the macrobenthic community due to high mortality rates. These results clearly demonstrate the weak resistance capacity of the macrobenthic communities from a pristine environment in case of oil contamination. They also highlight the need to carry out longer-term experiments in order to test the resilience capacities of this type of benthic system. A special attention to the shifts in macrobenthic species functional traits due to oil contamination should also be paid as they can markedly affect biogeochemical cycling with cascading effects on the ecological functioning of the whole ecosystem (Van Colen et al. 2012; Hale et al. 2014; Kristensen et al. 2014). This knowledge is fundamental in developing an efficient environmental management strategy against pollutions particularly for sensitive pristine marine protected areas such as Caleta Valdés.

Acknowledgments This work was funded by the Evaluationorientation de la Coopération Scientifique Sud - Ministerio de Ciencia, Tecnología e Innovación Productiva (ECOS Sud - MINCYT) collaboration program (Proyecto Caleta; action no A10U02) and the French Agence Nationale de la Recherche (project DECAPAGE; ANR CESA2011-006 01). We thank Anthony Maire for help in statistical analysis.

\section{References}

Aller RC (1982) The effects of macrobenthos on chemical properties of marine sediment and overlying water. In: McCall PL, Tevesz MJS (eds) Animal-sediment relations. Plenum, New York, pp 53-102

Almeda R, Wambaugh Z, Wang Z, Hyatt C, Liu Z, Buskey EJ (2013) Interactions between zooplankton and crude oil: toxic effects and bioaccumulation of polycyclic aromatic hydrocarbons. PLoS ONE 8(6):e67212. doi:10.1371/journal.pone.0067212

Alonso-Alvarez C, Perez C, Velando A (2007) Effects of acute exposure to heavy fuel oil from the Prestige spill on a seabird. Aquat Toxicol 84:103-110

Arimoro FO, Ikomi RB, Osalor EC (2007) The impact of sawmill wood wastes on the water quality and fish communities of Benin River, Niger Delta Area, Nigeria. Int J Sci Technol 2(1):1-12

Arndt S, Jørgensen BB, LaRowe DE, Middelburg JJ, Pancost RD, Regnier P (2013) Quantifying the degradation of organic matter in marine sediments: A review and synthesis. Earth-science reviews 123:53-86

Aston RJ (1973) Field and experimental studies on the effects of a power station effluent on Tubificidae (Oligochaeta, Annelida). Hydrobiologia 42(2):225-242 
Baker JM (1970) The effects of oils on plants. Environ Pollut 1(1):27-44 Banse K, Hobson KD (1974) Benthic errantiate polychaetes of British Columbia and Washington (No. 185). Fisheries and Marine Service, $111 \mathrm{pp}$

Banta GT, Andersen O (2003) Bioturbation and the fate of sediment pollutants. Vie Milieu 53:233-248

Belan TA (2003) Benthos abundance pattern and species composition in conditions of pollution in Amursky Bay (the Peter the Great Bay, the Sea of Japan). Mar Pollut Bull 46:1111-1119

Bellas J, Saco-Álvarez L, Nieto O, Bayona JM, Albaigés J, Beiras R (2013) Evaluation of artificially-weathered standard fuel oil toxicity by marine invertebrate embryogenesis bioassays. Chemosphere 90: $1103-1108$

Bertrand JC, Bonin P, Goutx M, Mille G (1993) Biosurfactant production by marine microorganisms. Potential application to fighting hydrocarbon marine pollution. J Mar Biotechnol 1:125-129

Bilyard GR (1987) The value of benthic infauna in marine pollution monitoring studies. Mar Pollut Bull 18:581-585

Blake JA, Ruff ER (2007) Polychaeta. In: Carlton TJ (ed) Intertidal invertebrates from California to Oregon, University of California Press, Los Angeles, California. University of California Press, Ltd. London, England, pp 309-410

Blanchard AL, Howard MF, Shaw DG (2002) Long-term investigation of benthic fauna and the influence of treated ballast water disposal in Port Valdez, Alaska. Mar Pollut Bull 44:367-382

Bolam SG (2011) Burial survival of benthic macrofauna following deposition of simulated dredged material. Environ Monit Assess 181:1327

Bonin P, Bertrand JC (1999) Involvement of bioemulsifier in heptadecane uptake in Pseudomonas nautica. Chemosphere 38:1157-1164

Borja A, Dauer DM (2008) Assessing the environmental quality status in estuarine and coastal systems: comparing methodologies and indices. Ecol Indic 8(4):331-337

Brinkhurst RO, Jamieson BGM (1971) Aquatic Oligochaeta of the world. Oliver and Boyd, Edinburgh, $860 \mathrm{pp}$

Carman KR, Fleeger JW, Pomarico SM (2000) Does historical exposure to hydrocarbon contamination alter the response of benthic communities to diesel contamination? Mar Environ Res 49:255-278

Christensen M, Banta GT, Andersen O (2002) Effects of the polychaetes Nereis diversicolor and Arenicola marina on the fate and distribution of pyrene in sediments. Mar Ecol Prog Ser 237:159-172

Comendatore MG, Esteves JL, Colombo JC (2000) Hydrocarbons in coastal sediments of Patagonia, Argentina: levels and probable sources. Mar Pollut Bull 40:989-998

Commendatore MG, Esteves JL (2007) An assessment of oil pollution in the coastal zone of Patagonia, Argentina. Environ Manag 40:814 821

Commendatore MG, Nievas ML, Amin O, Esteves JL (2012) Sources and distribution of aliphatic and polyaromatic hydrocarbons in coastal sediments from the Ushuaia Bay (Tierra del Fuego, Patagonia, Argentina). Mar Environ Res 74:20-31

Cuny P, Miralles G, Cornet-Barthaux V, Acquaviva M, Stora G, Grossi V, Gilbert F (2007) Influence of bioturbation by the polychaete Nereis diversicolor on the structure of bacterial communities in oil contaminated coastal sediments. Mar Pollut Bull 54:452-459

Cuny P, Cravo-Laureau C, Grossi V, Gilbert F, Militon C (2011) Biodegradation of hydrocarbons in bioturbated marine sediments. Microbial bioremediation of non-metals: Current Research:55-92

Dalton T, Jin D (2010) Extent and frequency of vessel oil spills in US marine protected areas. Mar Pollut Bull 60(11):1939-1945

Dargay JM, Gately D (2010) World oil demand's shift toward faster growing and less price-responsive products and regions. Energy Policy 38:6261-6277

Dauer DM (1993) Biological criteria, environmental health and estuarine macrobenthic community structure. Mar Pollut Bull 26:249-257
Dauvin JC, Ruellet T (2007) Polychaete/amphipod ratio revisited. Mar Pollut Bull 55:215-224

Dauvin JC, Bellan G, Bellan-Santini D (2010) Benthic indicators: from subjectivity to objectivity — where is the line? Mar Pollut Bull 60(7): 947-953

di Leonardo R, Bellanca A, Capotondi L, Cundy A, Neri R (2007) Possible impacts of $\mathrm{Hg}$ and $\mathrm{PAH}$ contamination on benthic foraminiferal assemblages: an example from the Sicilian coast, central Mediterranean. Sci Total Environ 388(1):168-183

Duport E, Gilbert F, Poggiale J-C, Dedieu K, Rabouille C, Stora G (2007) Benthic macrofauna and sediment reworking quantification in contrasted environment in the Thau Lagoon. Estuar Coast Shelf Sci 72:522-533

Echols BS, Smith AJ, Gardinali PR, Rand GM (2015) Acute aquatic toxicity studies of Gulf of Mexico water samples collected following the Deepwater Horizon incident (May 12, 2010 to December 11, 2010). Chemosphere 120:131-137

Engraff M, Solere C, Smith KE, Mayer P, Dahllöf I (2011) Aquatic toxicity of PAHs and PAH mixtures at saturation to benthic amphipods: linking toxic effects to chemical activity. Aquat Toxicol 102(3):142-149

Esteves JL, Commendatore MG, Nievas ML, Massara Paletto V, Amín O (2006) Hydrocarbon pollution in coastal sediments of Tierra del Fuego islands, Patagonia Argentina. Mar Pollut Bull 52:582-590

Fleeger JW, Carman KR, Nisbet RM (2003) Indirect effects of contaminants in aquatic ecosystems. Sci Total Environ 317:207-233

François F, Gerino M, Stora G, Durbec J-P, Poggiale J-C (2002) Functional approach to sediment reworking by gallery-forming macrobenthic organisms: modeling and application with the polychaete Nereis diversicolor. Mar Ecol Prog Ser 229:127-136

Gamito S (2008) Three main stressors acting on the Ria Formosa lagoonal system (Southern Portugal): physical stress, organic matter pollution and the landeocean gradient. Estuar Coast Shelf Sci 77:710-720

Gilbert F, Rivet L, Bertrand JC (1994) The in-vitro influence of the burrowing polychaete Nereis diversicolor on the fate of petroleumhydrocarbons in marine-sediments. Chemosphere 29:1-12

Gilbert F, Stora G, Bertrand JC (1996) In situ bioturbation and hydrocarbon fate in an experimental contaminated Mediterranean coastal ecosystem. Chemosphere 33:1449-1458

Gilbert F, Stora G, Desrosiers G, Deflandre B, Bertrand J-C, Poggiale J-C, Gagné J-P (2001) Alteration and release of aliphatic compounds by the polychaete Nereis virens (Sars) experimentally fed with hydrocarbons. J Exp Mar Biol Ecol 256(2):199-213

Gilbert F, Hulth S, Aller RC (2003) The influence of macrofaunal burrow spacing and diffusive scaling on sedimentary nitrification and denitrification: an experimental and model approach. J Mar Res 61:101125

Gilbert F, Hulth S, Grossi V et al (2007) Sediment reworking by marine benthic species from the Gullmar Fjord (Western Sweden): importance of faunal biovolume. J Exp Mar Biol Ecol 348(1):133-144

Gilbert F, Stora G, Cuny P (2015) Functional response of an adapted subtidal macrobenthic community to an oil spill: macrobenthic structure and bioturbation activity over time throughout an 18 months field experiment. Environ Sci Pollut R Online First Article. doi:10.1007/s11356-014-3906-4

Gomez Gesteira JL, Dauvin JC (2000) Amphipods are good bioindicators of the impact of oil spills on soft-bottom macrobenthic communities. Mar Pollut Bull 40:1017-1027

Gomez Gesteira JL, Dauvin JC (2005) Impact of the Aegean Sea oil spill on the Rîa of Ares and Betanzos fine sand community (Northwest Spain). Mar Environ Res 60:289-316

Gonzalez Egres A, Martins CC, Oliveira VM, Cunha Lana P (2012) Effects of an experimental in situ diesel oil spill on the benthic community of unvegetated tidal flats in a subtropical estuary (Paranagua Bay, Brazil). Mar Pollut Bull 64:2681-2691 
González J, Figueiras FG, Aranguren-Gassis M, Crespo BG, Fernández E, Morán XAG, Nieto-Cid M (2009) Effect of a simulated oil spill on natural assemblages of marine phytoplankton enclosed in microcosms. Estuar Coast Shelf Sci 83:265-276

Granberg ME, Hansen R, Selck H (2005) Relative importance of macrofaunal burrows for the microbial mineralization of pyrene in marine sediments: impact of macrofaunal species and organic matter quality. Mar Ecol Prog Ser 288:59-74

Grossi V, Massias D, Stora G, Bertrand JC (2002) Burial, exportation and degradation of acyclic petroleum hydrocarbons following a simulated oil spill in bioturbated Mediterranean coastal sediments. Chemosphere 48:947-954

Hale R, Mavrogordato MN, Tolhurst TJ, Solan M (2014) Characterizations of how species mediate ecosystem properties require more comprehensive functional effect descriptors. Sci Rep 4

Haney TA, Martin JW (2004) A new genus and species of leptostracan (Crustacea: Malacostraca: Phyllocarida) from Guana Island, British Virgin Islands, and a review of leptostracan genera. J Nat Hist 38(4): 447-469

Hartman O (1968) Atlas of the errantiate polychaetous annelids from California. Allan Hancock Foundation, University of Southern California, Los Angeles

Hartman O (1969) Atlas of the sedentariate polychaetous annelids from California. Allan Hancock Foundation, University of Southern California, Los Angeles

Hartwick EB, Wu RSS, Parker DB (1982) Effects of a crude oil and an oil dispersant (Corexit 9527) on population of the littleneck clam (Protothaca stamined). Mar Environ Res 6:291-306

Head IM, Jones DM, Röling WF (2006) Marine microorganisms make a meal of oil. Nat Rev Microbiol 4(3):173-182

Hedman JE, Gunnarsson JS, Samuelsson G, Gilbert F (2011) Particle reworking and solute transport by the sediment-living polychaetes Marenzelleria neglecta and Hediste diversicolor. J Exp Mar Biol Ecol 407:294-301

Holdway DA (2002) The acute and chronic effects of wastes associated with offshore oil and gas production on temperate and tropical marine ecological processes. Mar Pollut Bull 44(3): 185-203

Je J-G, Belan T, Levings C, Koo BJ (2003) Changes in benthic communities along a presumed pollution gradient in Vancouver Harbour. Mar Environ Res 57:121-135

Kennish MJ (1997) Practical handbook of estuarine and marine pollution. CRC, Boca Raton

Kristensen E, Penha-Lopes G, Delefosse M, Valdemarsen T, Quintana CO, Banta GT (2012) What is bioturbation? The need for a precise definition for fauna in aquatic sciences. Mar Ecol Prog Ser 446:285302

Kristensen E, Delefosse M, Quintana CO, Flindt MR, Valdemarsen T (2014) Influence of benthic macrofauna community shifts on ecosystem functioning in shallow estuaries. Mar Ecosyst Ecol 1:41

Kruskal WH, Wallis WA (1952) Use of ranks in one-criterion variance analysis. J Am Stat Assoc 47:583-621

Lee L-H, Lin H-J (2013) Effects of an oil spill on benthic community production and respiration on subtropical intertidal sandflats. Mar Pollut Bull 73:291-299

Lee RF, Page DS (1997) Petroleum hydrocarbons and their effects in subtidal regions after major oil spills. Mar Pollut Bull 34:928-940

$\mathrm{Lu}$ L (2005) Relationship between soft-bottom macrobenthic communities and environment variables in Singaporean waters. Mar Pollut Bull 51:1034-1040

Lu L, Wu RSS (2006) A field experimental study on recolonization and succession of macrobenthic infauna in defaunated sediment contaminated with petroleum hydrocarbons. Estuar Coast Shelf Sci 68:627634

Marino RG, Commendatore M, Sepúlveda M, Bucalá V, Nievas ML (2012) Determination of aromatic hydrocarbon of the soluble fraction in oil water using microextraction in solid phase with CG-EM.
IV Argentine Congress of Toxicology and Environmental Chemistry (SETAC). Congress Proceedings page 72 (in Spanish)

Massara Paletto V, Commendatore MG, Esteves JL (2008) Hydrocarbon levels in sediments and bivalve mollusks from Bahía Nueva (Patagonia, Argentina): an assessment of probable origin and bioaccumulation factors. Mar Pollut Bull 56(12):2100-2105

Mermillod-Blondin F, Rosenberg R (2006) Ecosystem engineering: the impact of bioturbation on biogeochemical processes in marine and freshwater benthic hábitats. Aquat Sci 68:434-442

Michaud E, Desrosiers G, Mermillod-Blondin F, Sundby B, Stora G (2006) The functional group approach to bioturbation: II. The effects of the Macoma balthica community on fluxes of nutrients and dissolved organic carbon across the sediment-water interface. J Exp Mar Biol Ecol 337:178-189

Miralles G, Grossi V, Acquaviva M, Duran R, Bertrand JC, Cuny P (2007) Alkane biodegradation and dynamics of phylogenetic subgroups of sulfate reducing bacteria in an anoxic coastal marine sediment artificially contaminated with oil. Chemosphere 68:13271334

Miserendino ML, Pizzolon LA (2000) Macroinvertebrates of a fluvial system in Patagonia: altitudinal zonation and functional structure. Arch Hydrobiol 150(1):55-83

Muniz P, Venturini N, Pires-Vanin A, Tommasi LR, Borja Á (2005) Testing the applicability of a Marine Biotic Index (AMBI) to assessing the ecological quality of soft-bottom benthic communities, in the South America Atlantic region. Mar Pollut Bull 50(6):624 637

National Research Council (NRC) (2003) Oil in the sea III: inputs, fates, and effects. National Academy Press, Washington

Nievas ML, Esteves JL (2007) Survey of the activities related with the oil exploitation in the patagonian coastal zone and preliminary data about waste of hydrocarbon in harbors. Project ARG/02/G31PNUD-GEF, Technical Report $\mathrm{N}^{\circ} 1$. Patagonia Natural Foundation, 1-74. ISBN 978-987-97411-5-3 (in Spanish)

Ocon CS, Capitulo A, Paggi AC (2008) Evaluation of zoobenthic assemblages and recovery following petroleum spill in a coastal area of Rio de la Plata estuarine system, South America. Environ Pollut 156:82-89

Penry DL, Weston DP (1998) Digestive determinants of benzo[a]pyrene and phenanthrene bioaccumulation by a deposit-feeding polychaete. Environ Toxicol Chem 17:2254-2265

Peso-Aguiar MC, Smith DH, Assis RCF, Santa-Isabel LM, Peixinho S, Gouveia EP, Almeida TCA, Andrade WS, Carqueija CRG, Kelmo F, Carrozzo G, Rodrigues CV, Carvalho GC, Jesus ACS (2000) Effects of petroleum and its derivatives in benthic communities at Baía de Todos os Santos/Todos os Santos Bay, Bahia, Brazil. Aquat Ecosyst Health Manag 3:459-470

Picard J (1965) Qualitative research on marine biotic communities of dragables soft substrates of the Marseille region. Collect Work Mar Station Endoume 36:1-160 (in French)

Pischedda L, Poggiale JC, Cuny P, Gilbert F (2008) Imaging oxygen distribution in marine sediments. The importance of bioturbation and sediment heterogeneity. Acta Biotheor 56(1-2):123-135

Pischedda L, Cuny P, Esteves JL, Poggiale J-C, Gilbert F (2012) Spatial oxygen heterogeneity in a Hediste diversicolor irrigated burrow. Hydrobiologia 680(1):109-124

Poulton BC, Callahan EV, Hurtubise RD, Mueller BG (1998) Effects of an oil spill on leafpack-inhabiting macroinvertebrates in the Chariton River, Missouri. Environ Pollut 99(1):115-122

Puente A, Juanes JA, Calderón G, Echavarri-Erasun B, García A, GarcíaCastrillo G (2009) Medium-term assessment of the effects of the Prestige oil spill on estuarine benthic communities in Cantabria (Northern Spain, Bay of Biscay). Mar Pollut Bull 58(4):487-495

Quintana CO, Tang M, Kristensen E (2007) Simultaneous study of particle reworking, irrigation transport and reaction rates in sediment 
bioturbated by the polychaetes Heteromastus and Marenzelleria, J Exp Mar Biol Ecol 352:392-406

Rhoads DC, McCall PL, Yingst JY (1978) Disturbance and Production on the Estuarine Seafloor: Dredge-spoil disposal in estuaries such as Long Island Sound can be managed in ways that enhance productivity rather than diminish it. Am Sci 577-586

Rivero MS, Elías R, Vallarino EA (2005) First survey of macroinfauna in the Mar del Plata Harbor (Argentina), and the use of polychaetes as pollution indicators. Rev Biol Mar Oceanogr 40(2):101-108

Roccatagliata D, Chiesa IL, Raffo MP, Gómez Simes E (2010) On the occurrence of the genus Paranebalia (Crustacea: Phyllocarida: Leptostraca) in northern Patagonia, Argentina. Zootaxa 2349:65-68

Rueda J, Camacho A, Mezquita F, Hernández R, Roca JR (2003) Effect of episodic and regular sewage discharges on the water chemistry and macroinvertebrate fauna of a Mediterranean stream. Water Air Soil Pollut 140:425-444

Ruiz F, Abad M, Bodergat AM, Carbonel P, Rodriguez-Lazaro J, Yasuhara M (2005) Marine and brackish-water ostracods as sentinels of anthropogenic impacts. Earth-Sci Rev 72:89-101

Seo J-Y, Kim M, Lim H-S, Choi J-W (2014) The macrofaunal communities in the shallow subtidal areas for the first 3 years after the Hebei Spirit oil spill. Mar Pollut Bull 82:208-220

Siegel S, Castellan NJ (1988) Nonparametric statistics for the behavioral sciences. McGraw Hill, New York

Solimi AG, Ruggiero A, Anello M, Mutsch Lechner A, Carchini GI (2000) The benthic community structure in mountain ponds affected by livestock watering in nature reserves of central Italy. Proc Int Assoc Theor Appl Limnol 27:1-5

Spormann AM, Widdel F (2000) Metabolism of alkylbenzenes, alkanes, and other hydrocarbons in anaerobic bacteria. Biodegradation 11: $85-105$

Stauffert M, Cravo-Laureau C, Jézéquel R, Barantal S, Cuny P et al (2013) Impact of oil on bacterial community structure in bioturbated sediments. PLoS ONE 8(6):e65347. doi:10.1371/journal.pone. 0065347
Thibodeaux LJ, Bierman VJ (2003) The bioturbation driven chemical release process. Environ Sci Tecnol: 252-258

Timmermann K, Christensen JH, Banta GT (2002) Modeling of advective solute transport in sandy sediments inhabited by the lugworm Arenicola marina. J Mar Res 60(1):151-169

Timmermann K, Banta GT, Johnsen AR, Andersen O (2008) Effects of the polychaetes Arenicola marina and Nereis diversicolor on microbial pyrene mineralization. Aquat Microb Ecol 50:197-207

Timmermann K, Banta GT, Klinge L, Andersen O (2011) Effects of bioturbation on the fate of oil in coastal sandy sediments - An in situ experiment. Chemosphere 82:1358-1366

UNEP/IOC (1992) Reference methods and technical bulletins for marine pollution studies

UNESCO (1999) http://whc.unesco.org/en/list/937. Accessed 25 September 2014

van Colen C, Rossi F, Montserrat F, Andersson MG, Gribsholt B, Herman PM et al (2012) Organism-sediment interactions govern posthypoxia recovery of ecosystem functioning. PLoS One 7(11): e49795

Venturini N, Muniz P, Bícego MC, Martins CC, Tommasi LR (2008) Petroleum contamination impact on macrobenthic communities under the influence of an oil refinery: integrating chemical and biological multivariate data. Estuar Coast Shelf Sci 78:457-467

Weston DP, Mayer LM (1998) In vitro digestive fluid extraction as a measure of the bioavailability of sediment-associated polycyclic aromatic hydrocarbons: sources of variation and implications for partitioning models. Environ Toxicol Chem 17:820-829

Wiese F, Ryan PC (2003) The extent of chronic marine oil pollution in southeastern Newfoundland waters assessed through beached bird surveys 1984-1999. Mar Pollut Bull 46:1090-1101

Yu OH, Lee H-G, Shim WJ, Kim M, Park HS (2013) Initial impacts of the Hebei Spirit oil spill on the sandy beach macrobenthic community west coast of Korea. Mar Pollut Bull 70:189-196

Zabbey N, Uyi H (2014) Community responses of intertidal soft-bottom macrozoobenthos to oil pollution in a tropical mangrove ecosystem, Niger Delta, Nigeria. Mar Pollut Bull 82:167-174 